\title{
The importance of place-based narrative in suburban forest planning
}

\author{
Julian Bolleter \& Paula Hooper
}

To cite this article: Julian Bolleter \& Paula Hooper (2020): The importance of place-based narrative in suburban forest planning, Journal of Urban Design

To link to this article: https://doi.org/10.1080/13574809.2020.1851594 


\title{
The importance of place-based narrative in suburban forest planning
}

\author{
Julian Bolleter (D) and Paula Hooper \\ The Australian Urban Design Research Centre, The University of Western Australia, Perth, Australia
}

\begin{abstract}
Urban forests provide numerous benefits to human health and wellbeing, the local urban environment and biodiversity. Despite this, many suburban areas are experiencing declining urban forests due to urban consolidation. In response, this paper proposes scenarios for improving canopy coverage using an Australian middle ring suburb as a case study. The paper employs a Delphi method assessment of the scenarios regarding their benefits and feasibility. The paper concludes that while experts focus on the technical dimensions of urban forest planning, planners should ensure that urban forest plans embody a place-based narrative that captures the public imagination and engenders stewardship.
\end{abstract}

\section{Introduction}

People have been planting trees in cities throughout civilization, in a tradition that extends back to Ancient Greece and China. Since the 1960s, urban forestry has developed into an area of professionalized practice. This practice engages government representatives, public and private land managers, researchers, arborists, activists, landscape contractors and the general community (Campbell, Svendsen, and Roman 2016, 1262; Nitoslawski, Duinker, and Bush 2016, 478). Now many cities have tree planting initiatives and urban forest strategies that encourage tree planting in urban areas (Department of Planning; City of Bayswater 2015; The City of Melbourne 2012; City of Vancouver 2018). This surge in urban forest strategies is not surprising given the multitude of benefits urban forests provide to human health, the local urban environment, biodiversity conservation and real-estate values.

While there exist numerous urban forest strategies, the majority are technical exercises, and generally, there has been a lack of vision to catch the public imagination. Meanwhile, in many cities, urban consolidation is occurring at the expense of urban forests and the ecosystem services they provide (Haaland and van den Bosch 2015; Brunner and Cozens 2013). Ultimately, these ecosystem services contribute to urban liveability and even viability. This paper purposefully sets out seven urban forest scenarios to address this situation most building on key planning theories - that could stimulate public interest, support and stewardship. Finally, the paper tests these scenarios against expert opinion in a two-stage Delphi method to ensure their validity. Such testing is important because policymakers and practitioners require urban forest scenarios that have been tested against expert opinion. 


\section{Background}

Urban forests provide a multitude of ecosystem services. These include cultural services such as physical health, mental health, spiritual value and sense of place, and biodiversity and regulating services such as stormwater mitigation, air purification, and shade and heatwave mitigation (McDonald 2015, 12).

\section{Cultural ecosystem services}

Contact with nature in urban areas - such as provided in gardens, parks and streets with high levels of canopy cover - has a critical role in people's quality of life, influencing health and wellbeing (Hartig et al. 2014). Indeed, research has proved that the presence of trees and vegetation encourages physical activity, reduces stress, improves mental health (Astell-Burt and Feng 2019), and promotes social interaction and a sense of belonging (Barron et al. 2019, 2). Overall, these lead to a plethora of health and wellbeing benefits across a person's life (Astell-Burt, Mitchell, and Hartig 2014).

Physical activity in shaded green spaces and streets (Hooper et al. 2015) counters sedentary lifestyles and is correlated with reductions in obesity, heart disease, some types of cancer, and with increased life spans (Pereira et al. 2013; Bell, Wilson, and Liu 2008; Yelenik and Levine 2011). In some instances, people can benefit from nature even without even engaging with it physically (Ulrich 1984; Cox et al. 2019). Indeed, the 'biophilia hypothesis,' suggests that people gain positive emotional responses from views of nature, even through a window (Barron et al. 2019, 2).

Parks and streetscapes with substantial tree cover are also essential to bolster social cohesion and sense of community. Indeed, such areas provide a venue for socializing and thus expand social ties (Kaźmierczak 2013). Research in the Netherlands indicated that people with more green spaces within one kilometre of their homes were 'healthier, less lonely and more socially supported' than those without substantial parks. This pattern was more pronounced in dense urban areas and for households with a low income, as well as children and the elderly (Maas et al. 2009).

Parks and streetscapes with significant tree cover are not only crucial for people, but also other species. There are more threatened species in Australian cities, per square kilometre, than elsewhere in the nation (Ives et al. 2016), a situation that mirrors North America (Schwartz, Jurjavcic, and O'brien 2002). In this context, parks with native trees, and understorey vegetation, can provide vital refugia for biodiversity, and 'stepping stones' that enable species movement through urban areas (Threlfall et al. 2017, 2015). Moreover, native street trees can also play a vital role in biodiversity conservation by augmenting ecological connectivity throughout urban areas (Mullaney, Lucke, and Trueman 2015; Ikin et al. 2013).

Urban biodiversity also allows residents to experience nature. As cities continue to sprawl, city dwellers are less likely to experience nature in their home or work environments (Miller and Hobbs 2002). Connection with nature in urban areas is therefore critical to avoid the extinction of 'nature's experience' (Miller 2005). Moreover, it engenders stewardship for nature in the neighbourhoods where people reside, but also beyond the cities' boundaries (Dunn et al. 2006). Engagement with nature in childhood supports a lifetime commitment to environmental protection (van den Born et al. 2018). 


\section{Regulating ecosystem services}

Urban forests improve the experience of the local urban environment through the provision of several vital regulating ecosystem services. A high degree of canopy cover in parks, streetscapes or private lots cool the microclimate and improve thermal comfort (Coutts et al. 2016). Trees cool the microclimate through evapotranspiration; however, this is a comparatively small contribution compared to their shading, which can lead to localized reductions in the temperature of 5 to $20^{\circ} \mathrm{C}$ (Coutts et al. 2016). The role of trees in microclimate regulation is becoming particularly significant in the context of increased temperatures in cities, due to the combined effects of climate change and Urban Heat Island (Duncan et al. 2019). These can present a severe threat to both children and older adults amidst extreme heat events (Kovats and Hajat 2008). Moreover, trees and understorey vegetation in parks, streets and private lots can provide several other ecosystem services, reducing noise from adjacent roads, filtering air pollution, and sequestering carbon (Bolund and Hunhammar 1999; Tzoulas et al. 2007). Vegetation also intercepts rainfall, reducing runoff into drains and maximizing water infiltration into the ground and aquifers (Nouri et al. 2013; Ossola, Hahs, and Livesley 2015).

Because of the plethora of benefits they provide, trees can also significantly uplift the value of the adjacent property. Indeed, in the Australian city of Perth researchers noted that, on average, the property price premium improved by AU\$14,500 for a $10 \%$ increase in tree canopy cover on adjacent public space (Panduro and Veie 2013; Pandit, Polyakov, and Sadler 2014). Moreover, they concluded that street trees adjacent to a house resulted in 'positive and sizable effects' on the sale price of the house of about AU\$17,000 (Pandit et al. 2013, 140).

\section{Urban forests in Perth}

Perth, the capital city of the state of Western Australia, is typically suburban and is characterized by a low residential density. Indeed, Perth has a population density of just 12.1 people per hectare making it the second least dense Australian capital city, second only to Brisbane with 9.2 people (Hurley, Taylor, and Dodson 2017, 124). Nonetheless, Perth's population is projected to increase from 1.8 million to 6.6 million by 2061 (Australian Bureau of Statistics 2013). As a result, State Government is attempting to densify existing suburban areas to curtail 'sprawl' which commentators regard as unhealthy, expensive, environmentally destructive and economically unproductive (Dodson and Sipe 2008; Kelly, Breadon, and Reichl 2011; Newman, Beatley, and Boyer 2009; Bolleter 2017, 2015).

In the pursuit of urban densification, Perth's planning strategies have concentrated on Transit-Oriented Development (Bolleter and Ramalho 2019). While Transit-oriented Development is the flagship of the State Government infill strategy, most infill development is the subdivision of suburban backyards. This form of development is referred to as ad hoc subdivision or 'background' urban infill and comprises modest projects delivering fewer than five group dwellings (Department of Planning, and Western Australian Planning Commission 2014, 107).

One effect of background infill in Perth has been a drop in urban forest cover in both the inner and middle suburban rings, otherwise known as the 'greyfields' (Brunner and Cozens 2013, 232; Bolleter 2016) (Figure 1). While there are exceptions, the areas with the lowest percentage of canopy cover tend to be those that have not repelled background infill 


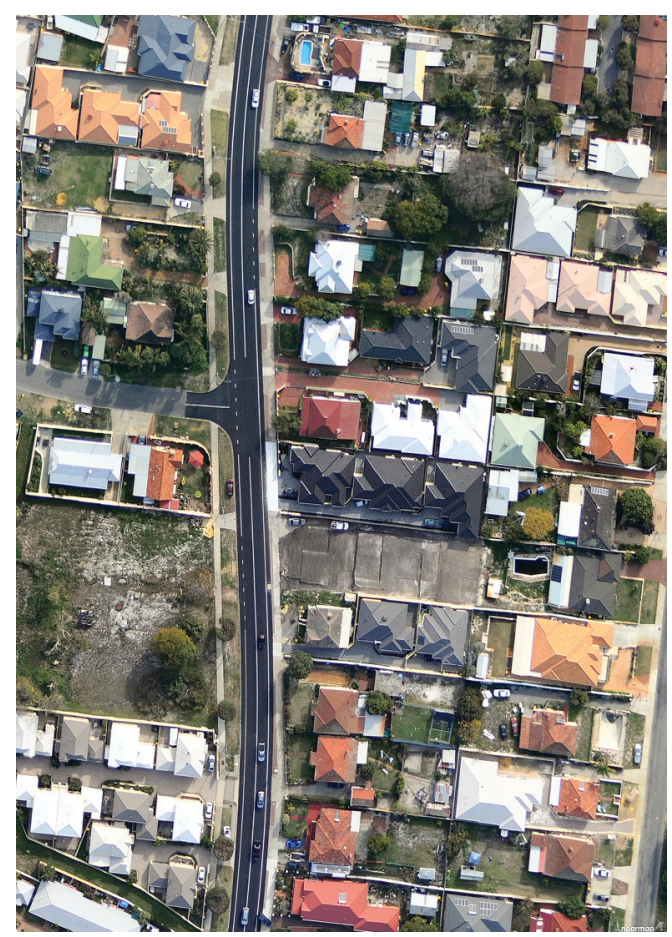

Figure 1. Background infill in Perth's inner and middle-ring suburbs typically compromises the urban forest. Photo courtesy of Nearmap.

(Department of Planning Lands and Heritage 2016). Examples are the inner and middle-ring Local Government Areas of South Perth, Bayswater, Stirling and Canning (all with ambitious infill targets) with the percentage of total canopy cover destroyed between just 2001-2004 amounting to $13 \%, 12 \%, 11 \%$ and $11 \%$ respectively (McManus 2010,350 ). One reason for this is that a substantial proportion of trees are located on private land where they are given little 'protection against the exigency of meeting development aspirations' (Brunner and Cozens 2013, 232). Indeed, in Perth, development is controlled through the State Government administered R-Codes (West Australian Planning Commission, and Department of Planning 2015) which provides no regulatory protection of trees. Nonetheless, other State Government and Local Government administered guidelines have been developed to encourage the retention and propagation of urban forests (Department of Planning Lands and heritage 2018, 4; City of Bayswater 2015).

\section{The study area}

Given the concerning reduction in canopy cover, this paper advances scenarios for increasing tree canopy coverage in the Perth middle ring Local Government Area of Bayswater and tests them using a survey of experts. Bayswater is situated six kilometres northeast of Perth's central business district in the middle-suburban belt (Figure 2). The Local Government Area is typically suburban and has a reasonable current tree canopy coverage of $13 \%$ (Figure 3). Nonetheless, Bayswater also has an ambitious infill target of 8,500 new dwellings by 2031 (Western Australian Department of Planning 2010) which 


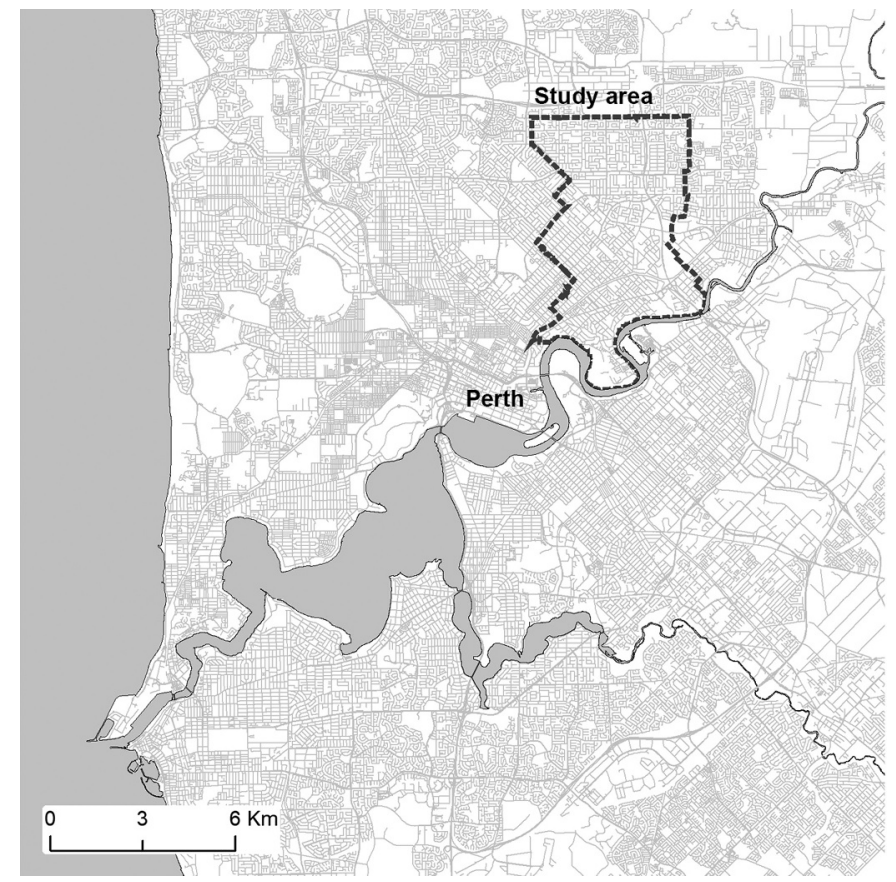

Figure 2. The Bayswater study area is situated six kilometres northeast of Perth's central business district in the middle-suburban belt.

could conflict with its aspirational plan to dramatically increase urban forest canopy cover (City of Bayswater 2018, 1). The scenarios proposed are, within reason, generalizable to the middle-ring suburbs of other Australian, North American and United Kingdom cities (amongst others) which are experiencing urban consolidation (Hagan 2017, 469).

\section{Methods}

This paper records the findings from a research project conducted in 2019/2020, for the City of Bayswater, which produced scenarios to inform an increase in canopy coverage from approximately 13\%, to $20 \%$ by the year 2025 (City of Bayswater 2018, 1). This percentage equates to 117,000 new trees if each tree is five-metres in diameter. The research question that guided this enquiry was:

What scenarios can local governments adopt for boosting urban forests in densifying suburbs that provide a multitude of benefits to residents yet remain feasible for implementation?

The study employed research methods in the following stages to answer this question. Firstly, a design research exercise was conducted to generate a variety of different scenarios for spatializing the seven per cent increase in urban canopy cover. While some question whether 'design research' is a valid research method, Swaffield and Deming assert that 'design may become research if it is planned and undertaken as a systematic process of inquiry, with a clear theoretical framework and research questions' $(2010,206)$. As such, the 


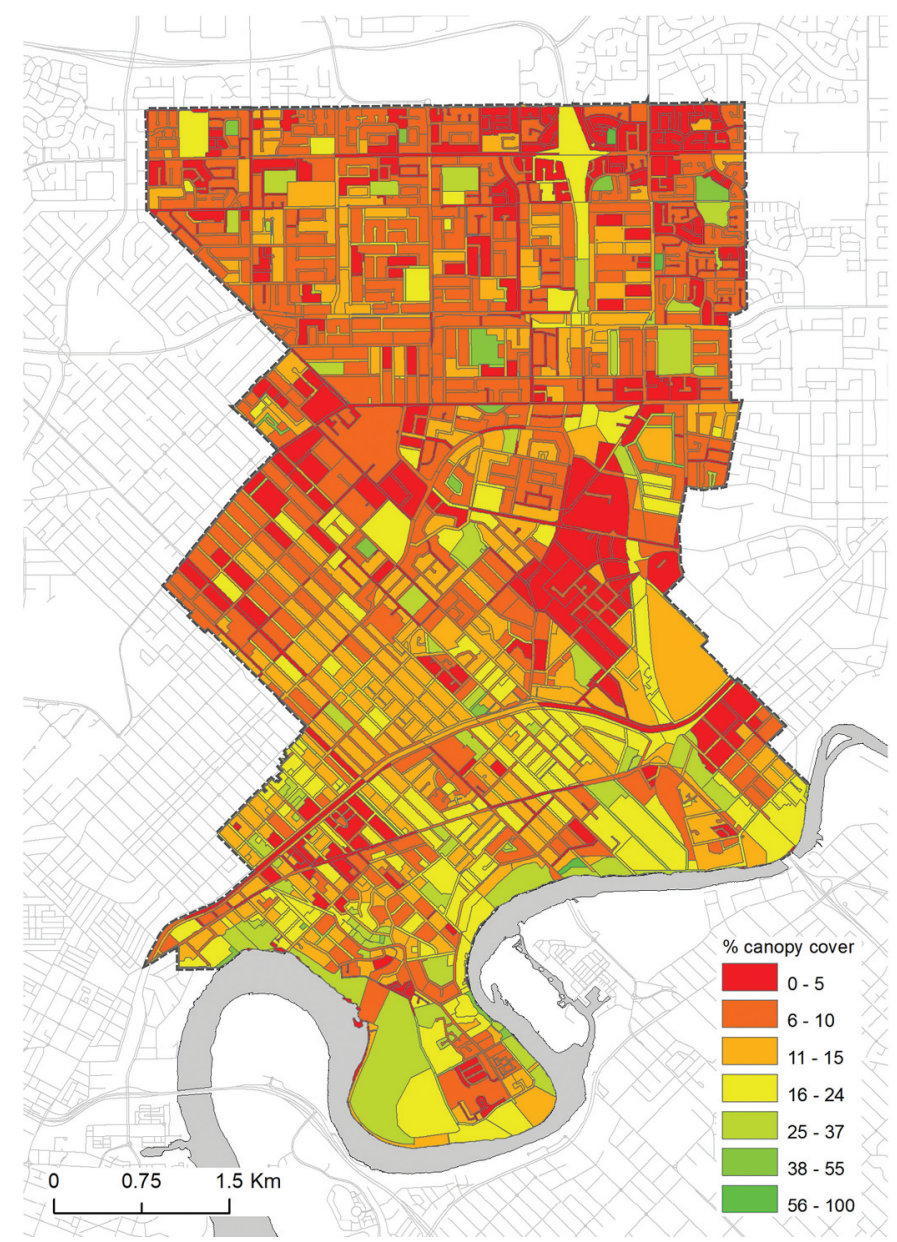

Figure 3. City of Bayswater urban forest canopy cover (\%) 2016. Data courtesy of the Department of Planning, Lands and Heritage.

seven scenarios were conceived with specific reference to the research question and relevant theory, and tested through a rigorous process of evaluation.

\section{The urban forest scenarios}

The first urban forest scenario, The Kid's Forest, concentrated tree planting around playgrounds, schools, day-care, medical and aged care centres, and adjacent streets (within $400 \mathrm{~m}$ ) of all school sites within the City of Bayswater. The scenario built on research indicating that heat stress, which is becoming increasingly common in Perth's long, hot and dry summers, disproportionally affects vulnerable groups such as children and older people, and as such urban forest planning should seek to protect such groups (Lenzholzer 2015, 23). It also sought to address that Australia is in the midst of a childhood obesity epidemic (Timperio et al. 2008), a situation which inviting and comfortable streets and parks could address by encouraging children to walk to school or the local park. Indeed, research has shown that children with 
better access to parks had consistently lower Body Mass Index. The inference is that kids with parks nearby spent energy both walking to the park and then playing there, and this extra bit of exercise kept the children slightly thinner (McDonald 2015, 180).

The second scenario, the Parks Equalizer, distributed the seven per cent canopy cover to parks with a current low canopy cover. Given that parks are crucial to the provision of mental and physical health benefits, and an important forum for socializing (McDonald $2015,198)$, the scenario seeks to bolster canopy cover in the parks, and equalize this across the entire Local Government Area.

The third scenario, the Streets Equalizer, distributed the seven per cent canopy cover increase to street verges (excluding freeways) with a current low canopy cover. Bolstering canopy cover in streetscapes is important because streetscapes provide a setting for social interaction, play and passive recreation (Ben-Joseph 2007, 505) which enhances both health and wellbeing. Streetscape plantings also have the potential to reduce ambient temperature, improve air quality and assist with urban water management.

The fourth scenario, the Green Stream, focussed tree planting in upgraded open drains and foreshores and adjacent street verges. This scenario builds on Water Sensitive Urban Design theory which seeks to reduce the quantity of stormwater and improve water quality (Wong 2006, 215). Indeed, urban forests can intercept rainfall, reducing runoff into stormwater drains and maximizing water infiltration into the ground (Nouri et al. 2013; Ossola, Hahs, and Livesley 2015)

The fifth scenario, the Green Micro-Grid focussed tree planting in streets connecting transit hubs, parks and schools with an overarching aim of increasing active transport to amenities but also train stations so to increase mass transit usage. This scenario builds on Transit Oriented Development approaches which aim for pedestrian-friendly neighbourhoods to support transit by providing easy pedestrian access for transit users (Calthorpe and Fulton 2015, 336).

The sixth scenario, the Green Funnel focussed tree planting in streets, parks, and private land in areas the City of Bayswater has designated biodiversity corridors. It is well documented that urbanization negatively affects many species, but also that urban areas can be designed to support wildlife (Ikin et al. 2013, 295). By providing predominately native streetscapes and parks, suburban areas can support biodiversity, particularly native bird species (Ikin et al. 2013, 295).

The last scenario, The High-Density Forest focussed tree planting in areas of the Local Government Area that the City of Bayswater, has zoned for increased urban densities. Some commentators advise that as urban density increases planners should increase the amount of green space in an area, thus offsetting the reduction of private open space. The theory presumes that residents will compensate for limited access to private open space by more frequently using public open spaces such as parks, a notion referred to as the 'compensation hypothesis' (Byrne, Sipe, and Searle 2010, 164). While it is extremely difficult to create 'new' green open space in existing areas, this scenario increases the density of canopy coverage in combination with increases in urban density (Bolleter and Ramalho 2014).

Readers should note that the urban forest scenarios were indicative and did not resolve details such as the diversity of native and non-native tree species. Nonetheless, the diversity of tree species is crucial to the urban forest's resilience concerning disturbances like pests, diseases, extreme weather events, and other climatic changes (Nitoslawski, 
Duinker, and Bush 2016,480 ) and its ability to contribute to local biodiversity protection (Nitoslawski, Duinker, and Bush 2016, 471).

The scenarios also generally focus on opportunities for increasing the urban forest in Local Government managed land (e.g., streetscapes, parks, school sites) and not on privately owned land. This choice reflects that the City of Bayswater, has little agency to regulate tree planting, and protection, on private land or land controlled by public utilities. Indeed, the literature indicates that tree planting on land owned by public utilities or privately owned property is 'high risk' (Department of Planning Lands and heritage 2018, p. 19). Conversely, the literature and our findings indicate that parks are generally low-risk because planners have designated these 'as spaces for biodiversity, recreation and relaxation with few development pressures' (Department of Planning Lands and heritage 2018, 20). Nonetheless, the proportion of trees are on private land can exceed 60\% (In Brunner and Cozens 2013, 234). While these areas are largely beyond the scope of this paper, they remain of importance.

\section{Delphi technique evaluation of urban forest scenarios}

With the seven urban forest scenarios designed and visualized, a Delphi method was then employed to assess these scenarios. This approach builds on other urban forest related papers which utilize a Delphi method to assess options (Barron, Sheppard, and Condon 2016). The Delphi method is an efficient method for collecting informed judgements from a group of experts on a specific problem. It enables controlled communication among a group of experts, allowing them, collectively, to deal with a complicated problem effectively (Perveen, Kamruzzaman, and Yigitcanlar $2017,6)$. In a Delphi method, a facilitator develops a questionnaire and issues it to a sample of selected experts. The Delphi method guarantees the anonymity of experts and as such warrants that the results are not biased, due to the dominance of a single group or individual. Participants in Delphi methods generally feel comfortable in sharing their feelings on issues anonymously, which leads to a improved response rate in comparison to workshops and focus groups (Perveen, Kamruzzaman, and Yigitcanlar 2017, 6).

For this project, the Delphi method included the following stages: Firstly, a panel of 15 experts was assembled. These included local government strategic planning officers, parks and gardens managers, civil engineers, directors of technical services, community engagement advisors, sustainability and environment managers, recreation managers, arborists and place managers. The study employed a non-random purposive sampling to deliberately target individuals with relevant expertise (Kelley et al. 2003, 264). The participants met together as a group before the Delphi survey, but this did not re-occur.

Secondly, the design scenarios were distributed to the panel of experts for review via an online survey. In total, 11 respondents completed the survey. The scenario assessment framework was based on the three themes of economic benefits, environmental benefits and social benefits (Table 1). Respondents were asked to assess the seven urban forest scenarios against an assessment framework, indicating how strongly they agreed or disagreed that the urban forest scenario would deliver economic, environmental and social benefits. Where, 1 = strongly disagree; 2 = disagree; 3 = neither agree nor disagree; $4=$ Agree; 5 = strongly agree. The survey also asked whether the scenario was feasible. 
Table 1. This table shows the urban forest benefits respondents used to rate each scenario under each theme.

\begin{tabular}{|c|c|}
\hline Economic benefits & $\begin{array}{l}\text { Increased property values: Trees visually enhance an area and increase property values } \\
\text { Reduced energy usage: Trees strategically planted to provide shade from the sun can cool } \\
\text { buildings by up to } 7^{\circ} \mathrm{C} \text {, which can reduce air conditioning costs. } \\
\text { The increased life span of infrastructure and assets: Tree shade can increase the life span of } \\
\text { infrastructures such as roads which in turn reduce maintenance and replacement costs. } \\
\text { Reduced health care costs: Studies indicate that greener suburbs encourage people to exercise } \\
\text { more and provides better mental health outcomes. Increasing the physical and mental health } \\
\text { of people results in a reduction in community health care costs }\end{array}$ \\
\hline $\begin{array}{l}\text { Environmental } \\
\text { benefits }\end{array}$ & $\begin{array}{l}\text { Shading and cooling: Trees provide shade and reduce the surrounding air temperature through } \\
\text { the process of evapotranspiration. } \\
\text { Improved air quality: Trees trap and absorb air pollutants such as dust and particulate matter } \\
\text { which improves air quality. } \\
\text { Reduced stormwater runoff: Trees slow stormwater flow rates, reduce stormwater runoff and } \\
\text { improve water quality by capturing and filtering water through their leaves and root systems. } \\
\text { Carbon sequestration: Trees help to mitigate the impacts of global warming by capturing and } \\
\text { storing carbon and removing it from the atmosphere. } \\
\text { Provision of food and habitat for wildlife: Trees provide food sources and shelter for animals such } \\
\text { as birds, mammals, insects and other wildlife } \\
\text { Reduced UHI effect: Trees reduce UHI effects through shading and evapotranspiration }\end{array}$ \\
\hline Social benefits & $\begin{array}{l}\text { Enhanced sense of place: Tree-lined streets and well-designed green spaces enhance the urban } \\
\text { form, which facilitates a strong sense of community connection to an area. } \\
\text { Reduced sun and heat-related illnesses: The provision of shade and a subsequent reduction in air } \\
\text { temperature can help reduce mortality rates, especially amongst the most vulnerable, e.g., the } \\
\text { young, the elderly and homeless people. } \\
\text { Improved community cohesion: Green urban spaces, especially those providing well-shaded } \\
\text { areas, encourage the local community to gather and interact, and this facilitates community } \\
\text { cohesion. } \\
\text { Improved physical and mental health: Providing green spaces within urban areas encourages } \\
\text { people to undertake outdoor activities such as exercise and promotes interaction with others } \\
\text { which has a variety of positive health effects for both physical, mental and social wellbeing. } \\
\text { Reduction in anti-social behaviour: Research indicates that green spaces have a positive influence } \\
\text { on the social behaviour of a community and can reduce the level of particular illegal activities. }\end{array}$ \\
\hline Feasibility & $\begin{array}{l}\text { The scenario is likely to be accepted by the community and in particular individual landholders. } \\
\text { The scenario cost is not prohibitive. } \\
\text { This scenario can be implemented within existing governance arrangements. } \\
\text { This scenario is resilient to a drying climate and sea-level rise. }\end{array}$ \\
\hline
\end{tabular}

The benefits descriptors were developed from the City of Bayswater's existing urban forest strategy 'Greening our Garden City' which they based on a comprehensive process of community engagement, through three separate workshops within the Local Government Area that focussed on community environmental groups, residents, local businesses and developers respectively (City of Bayswater 2015, 15).

Thirdly, the initial expert assessment and justifications were analysed through the computation of scores for each of the design scenarios. For each design scenario, the scores were summed for each theme rated by the experts. A total score for each design scenario was also created by summing the scores across all themes.

Fourthly, the collective responses to the design scenarios from stage two were provided to the experts via a second online survey, and then they were asked to review their initial forecasts in light of the feedback. They were also asked to rank their first, second and third preference.

Fifthly, the final assessment was developed by aggregating the experts' preferences (Hyndman and Athanasopoulos 2018). 


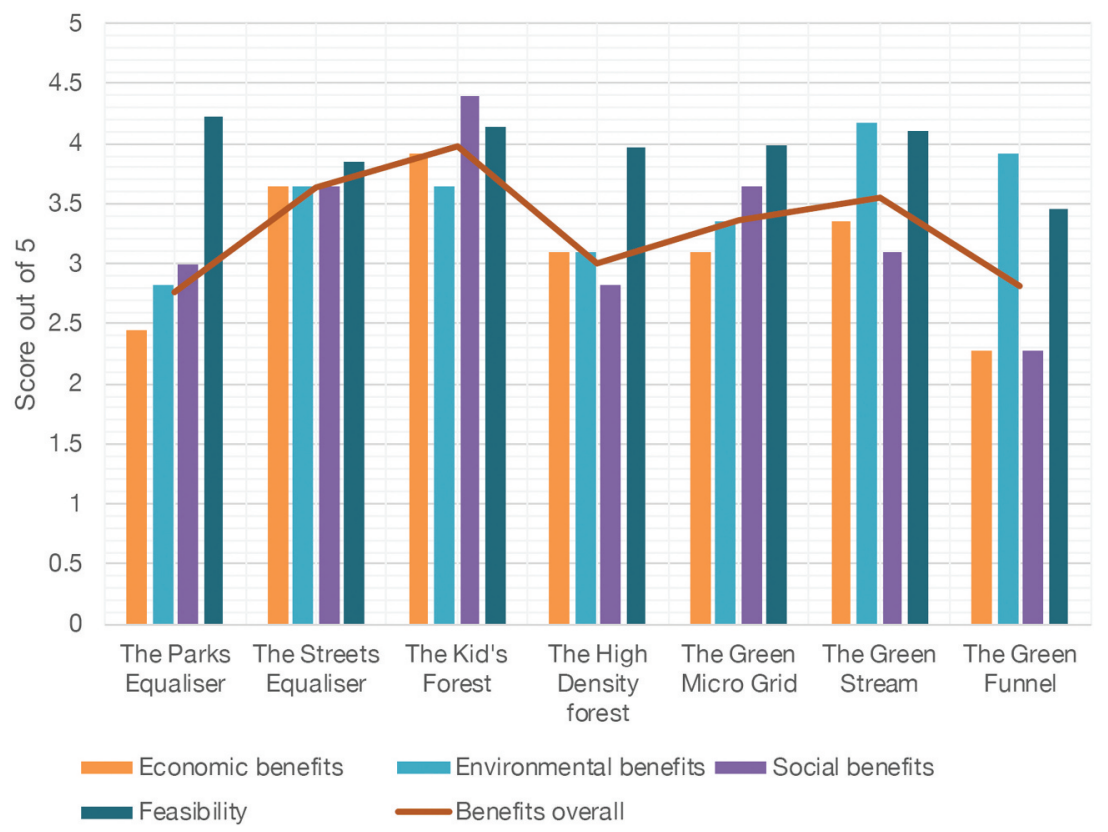

Figure 4. Delphi stage one survey results: The experts ranked 'The Kid's Forest' and 'The Streets Equalizer' highly in terms of the benefits provided while 'The Parks Equalizer' ranked highly in terms of feasibility.

\section{Results}

This research paper tables aspirational scenarios for increasing canopy coverage on public land using an Australian middle ring suburb as a case study. The study employed a Delphi method assessment of the scenarios regarding their respective benefits and feasibility. In total, 11 respondents (73\%) completed the survey. The results consistently ranked 'The Kid's Forest' and 'The Streets Equalizer' highly (Figure 4). Discussed below are the scenarios in order of their ultimate ranking in the stage two survey, and the comments respondents made regarding their benefits and feasibility.

\section{The Kid's Forest}

The highest-ranked scenario, based on the experts most 'preferred' scenario, was entitled 'The Kid's Forest.' In this scenario, tree planting was concentrated around playgrounds, schools, day-care centres, medical and aged care, and adjacent streets (within $400 \mathrm{~m}$ ) of all school sites within the City of Bayswater. To achieve the canopy cover increase the City of Bayswater requires, the cover in these parks and streets would have to increase from six to $55 \%$ (Figures 5 and 6).

Respondents noted that this scenario was 'strong' and 'will protect the most vulnerable members of our community.' They also felt it resonated with the 'literature which is coming out about children's early experiences of nature, and how it shapes their ability to connect, and also then feel some responsibility for nature as adults.' Moreover, they noted it could lead to greater 'walkability and safety of access to schools' because 'higher canopy coverage over verges helps to reduce traffic speeds.' They also considered that it would 'increase the volume of natural shade' around playgrounds 'as opposed to using artificial shade.' 


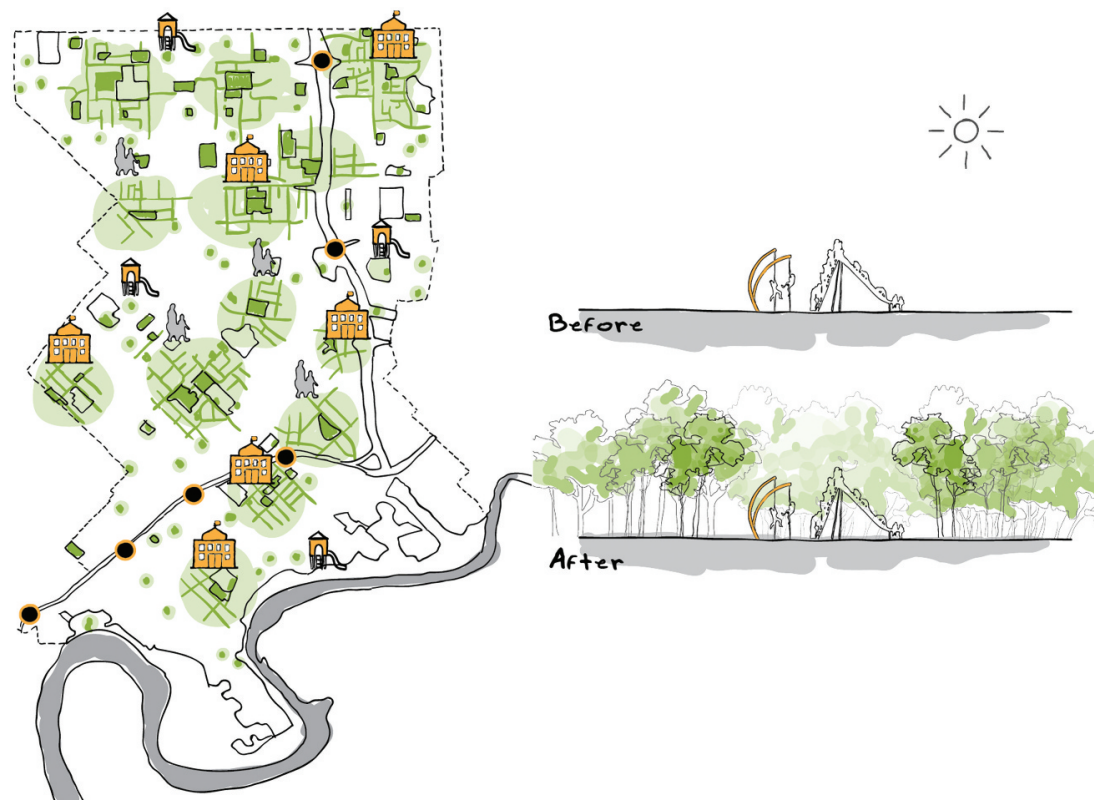

Figure 5. Kid's Forest: In this concept, tree planting was focussed on playgrounds, schools, day-care centres, medical centres, aged care, and adjacent streets within $400 \mathrm{~m}$.
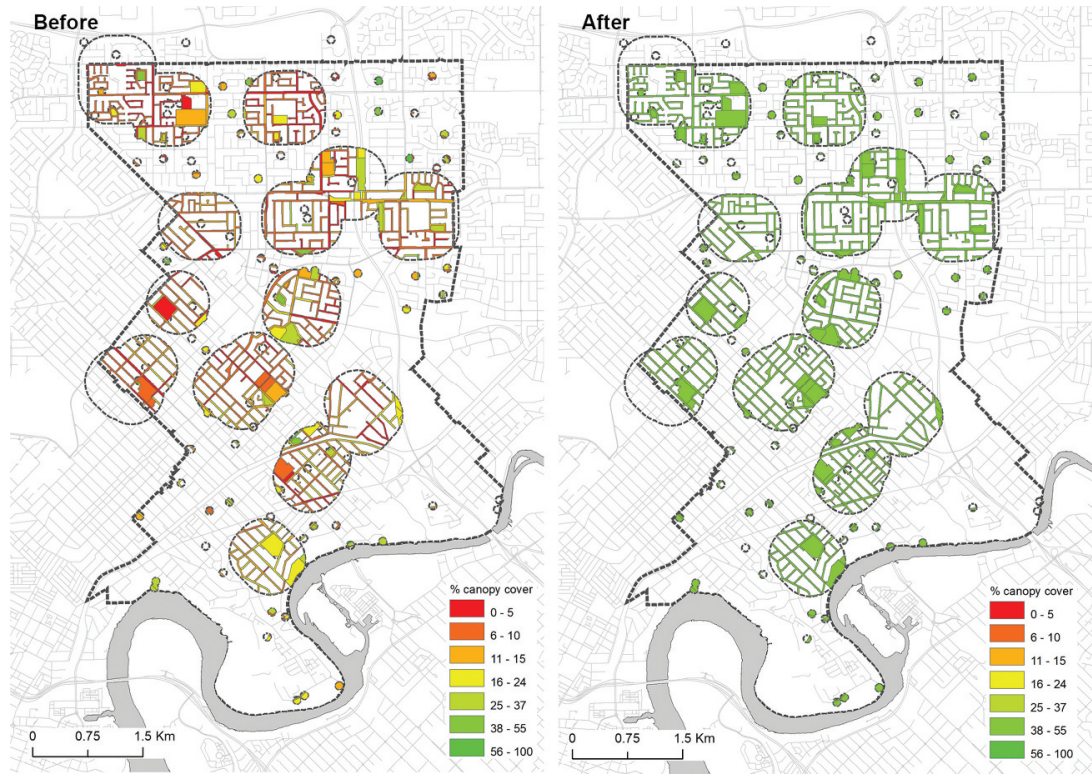

Figure 6. Kid's Forest: To achieve the overall 7\% increase targeted by the City of Bayswater parks and streets within these zones requires a canopy cover increase from 6 to 55\%.

However, some respondents were concerned that it 'may be seen as inequitable by those who are not in one of the identified areas' and that due to it not being 'evenly spread through the suburbs, it would create an inequity of benefits.' Finally, the scenario 
requires negotiating with 'private landowners and state government [the Department of Education] who does not have tree cover as a priority.' Nonetheless, others felt the 'scenario is easily implemented and targets key vulnerable groups.'

\section{The Parks Equalizer}

The second-highest ranked scenario was entitled the 'The Parks Equalizer.' In this scenario, the seven per cent canopy cover was distributed to parks with a current low canopy cover. To achieve the increase the City is targeting, requires parks across the Local Government Area to increase from an average canopy cover of $23 \%$ to $60 \%$ (Figures 7 and 8). Respondents felt that this scenario 'would be quick and easy to implement and is likely to be most easily accepted by the community as long as it is not blocking views.' Respondents felt that this scenario would be best suited to those parks which do not have an active 'sports provision' but 'currently are particularly low in a canopy coverage.'

Nonetheless, respondents had several reservations. Some worried about community opposition because they have experienced 'instances where we have had to go into parks and remove trees because there has been community opposition to the amount of coverage in a reserve. This is because it impacted on the grass growth, resulted in twigs in the playground and blocked views and restricted the use of park particularly for active sports.' Due to the potential threat of community opposition, respondents felt that they would need to 'tailor what we do for certain areas.' Finally, respondents thought that the scenario would only 'benefit only those that visit the reserves' and the 'only potential energy savings will be reduced reticulation costs' with little improvement for houses.

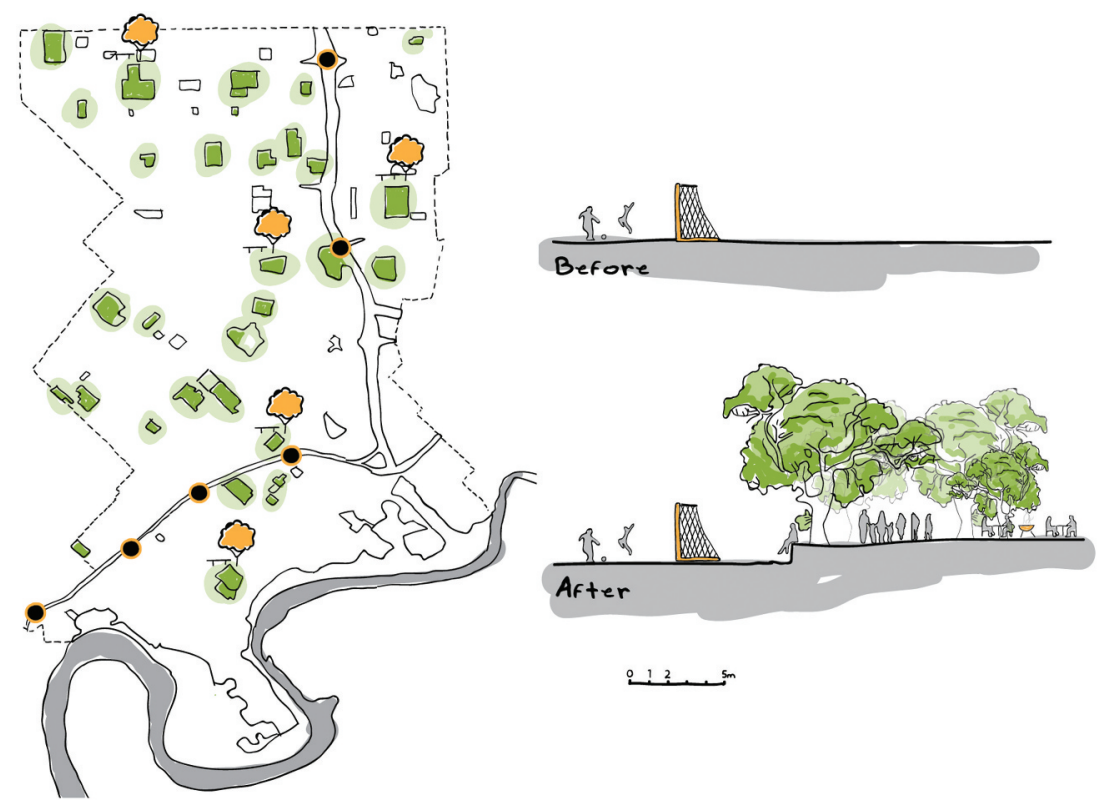

Figure 7. The Parks Equalizer: In this concept tree planting was focussed in parks with a low existing canopy cover to achieve parity across the City of Bayswater. 

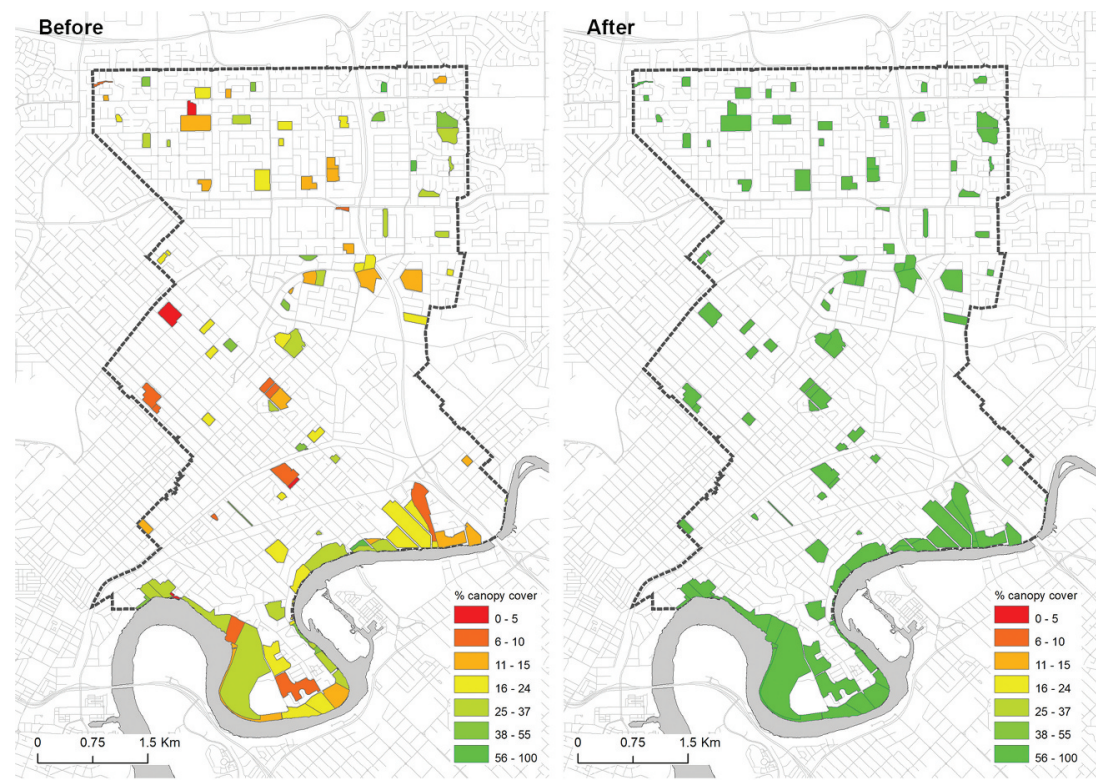

Figure 8. The Parks Equalizer: To achieve the overall 7\% increase targeted by the City of Bayswater requires park canopy cover to increase from $23 \%$ to $60 \%$.

\section{The Streets Equalizer}

The third-ranked scenario was entitled 'The Streets Equalizer.' In this scenario, the seven per cent canopy cover was directed to road verges (excluding freeways) with a current low canopy cover. To achieve the canopy cover increase the City is targeting, requires road reserves to increase in canopy cover from 10\% to 30\% (Figures 9 and 10).

Respondents noted that this scenario delivered substantial 'psychological benefits' to adjacent 'individual households' who 'have more trees in streets, as opposed to in the parks.' They also felt that increased tree planting in streets would improve 'liveability' and increase property values. Finally, respondents felt the scenario 'allows for equal access to the benefits for the entire community, due to the proximity to every residence.'

Nonetheless, respondents raised several concerns. Some noted that it would require the 'undergrounding of overhead infrastructure' such as power-poles that would require a 'significant investment.' Moreover, respondents pointed out that the maintenance of the trees will be a higher cost (than trees in parks) both 'because the trees are spread out, but also the expectation of community will be regular pruning to individual resident requirements.' While respondents referred to the 'equality' of tree distribution, others raised concerns the scenario will trigger a backlash from 'people who do not want a tree on their verge.' These could be prompted by 'reduced verge parking, leaf drop and interfering with new crossovers as part of redevelopment.' 


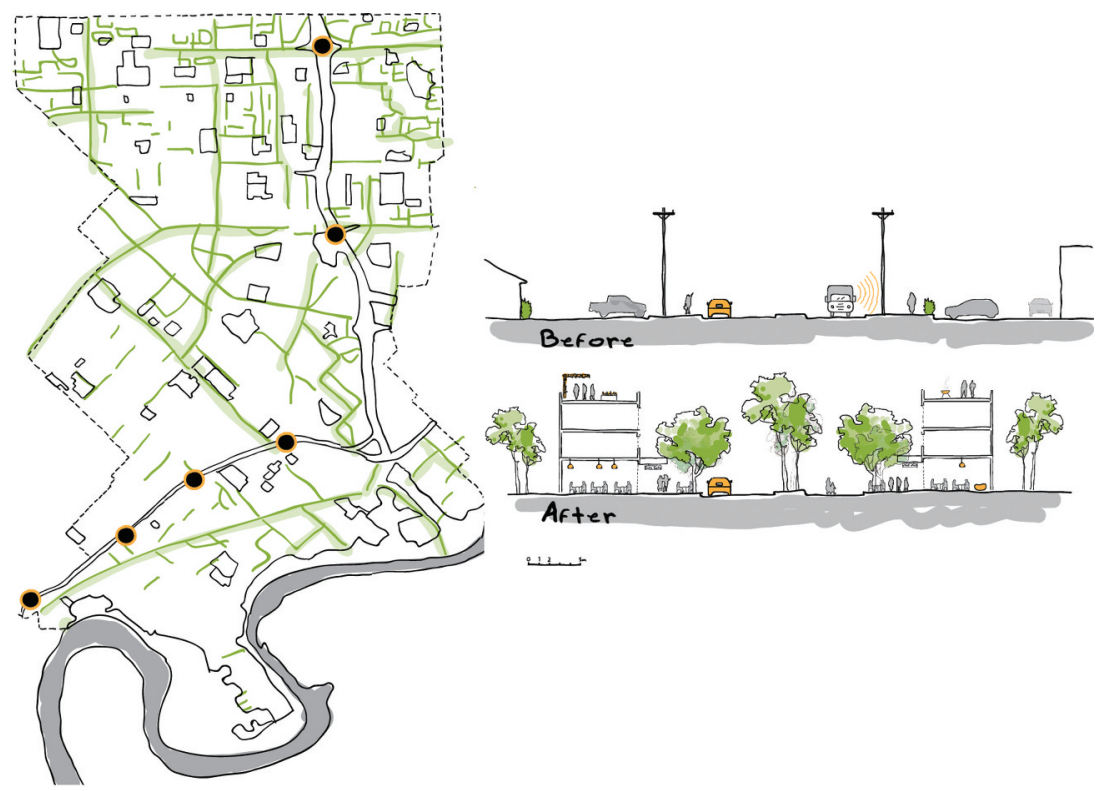

Figure 9. The Streets Equalizer: In this concept, the 7\% canopy cover increase was distributed to road verges (excluding freeways) with a current low canopy cover.
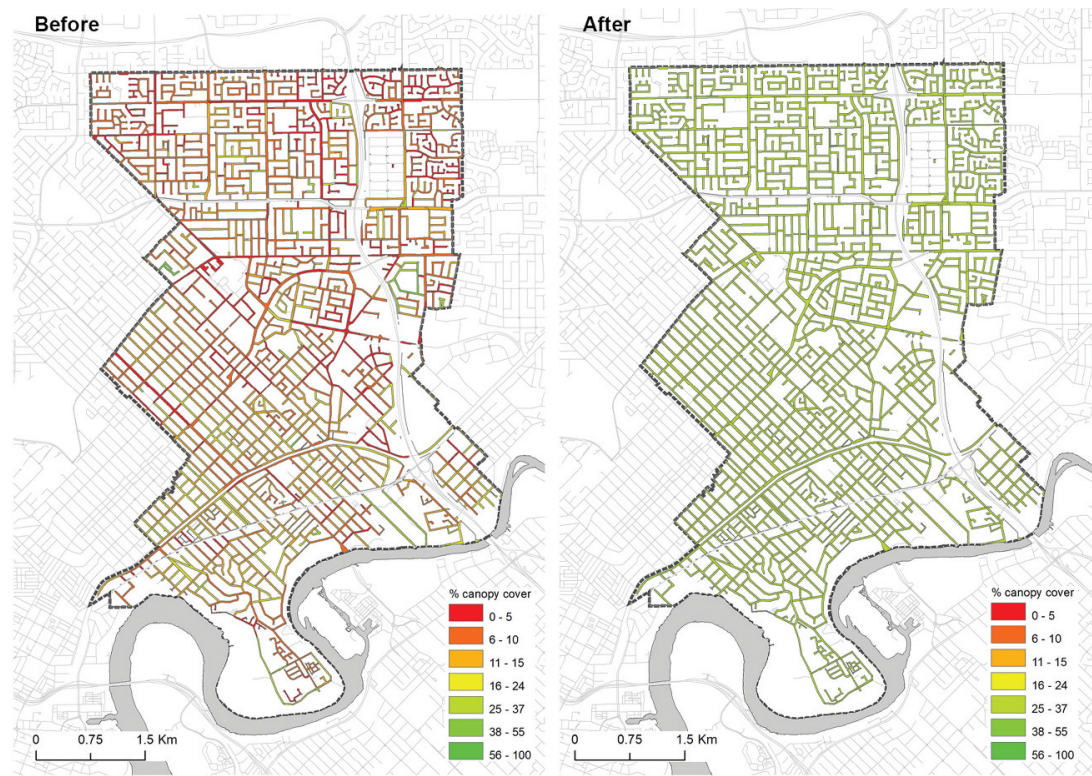

Figure 10. The Streets Equalizer: To achieve the overall 7\% increase targeted by the City of Bayswater requires streets to have a canopy cover increase from $10 \%$ to $30 \%$.

\section{The Green Stream}

The fourth-ranked scenario was entitled 'The Green Stream.' In this scenario, tree planting was focussed in upgraded drains and foreshores, and adjacent streets, in a bid to retrofit Water Sensitive Urban Design principles to the study area's extensive matrix of drains that 
currently serve flood mitigation functions. To achieve the City's overall target of a seven per cent increase in canopy cover requires these drainage reserves, foreshore parks and streets to increase from 12 to $52 \%$ canopy cover (Figures 11 and 12).
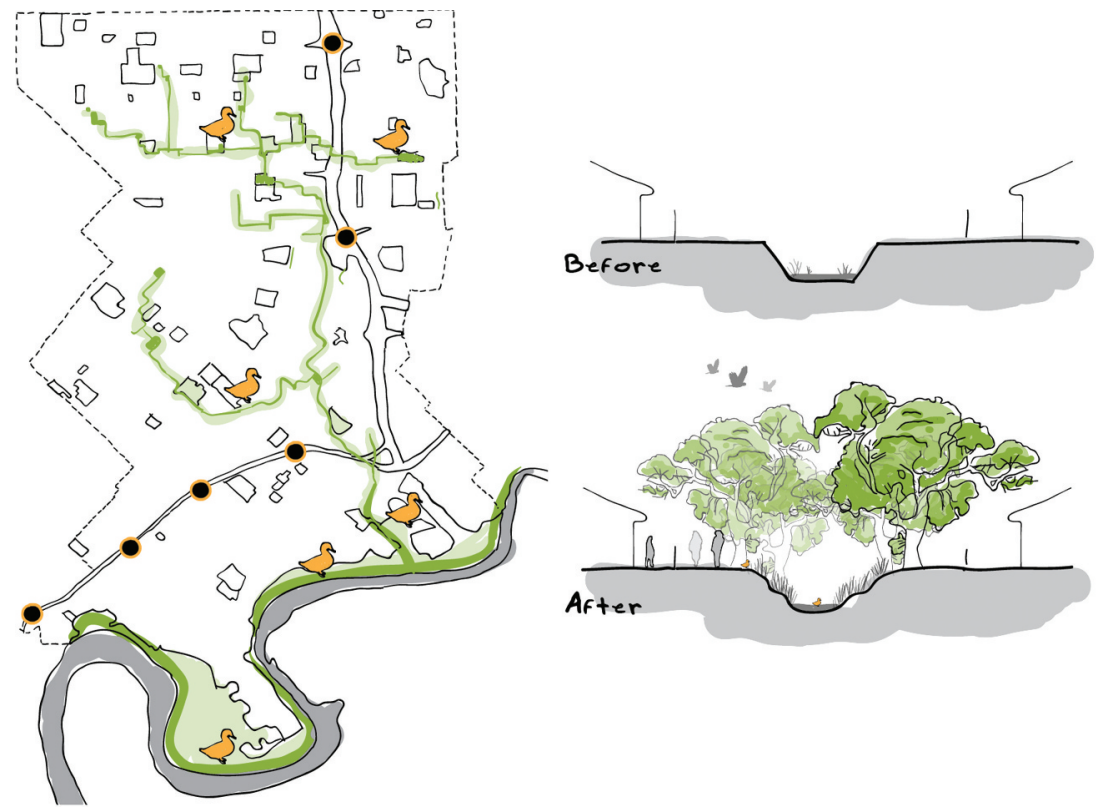

Figure 11. The Green Stream: In this concept, tree planting was focussed in streets around upgraded drains and foreshores in a bid to retrofit Water Sensitive Urban Design to Bayswater's extensive matrix of drains which currently only serve flood mitigation functions.
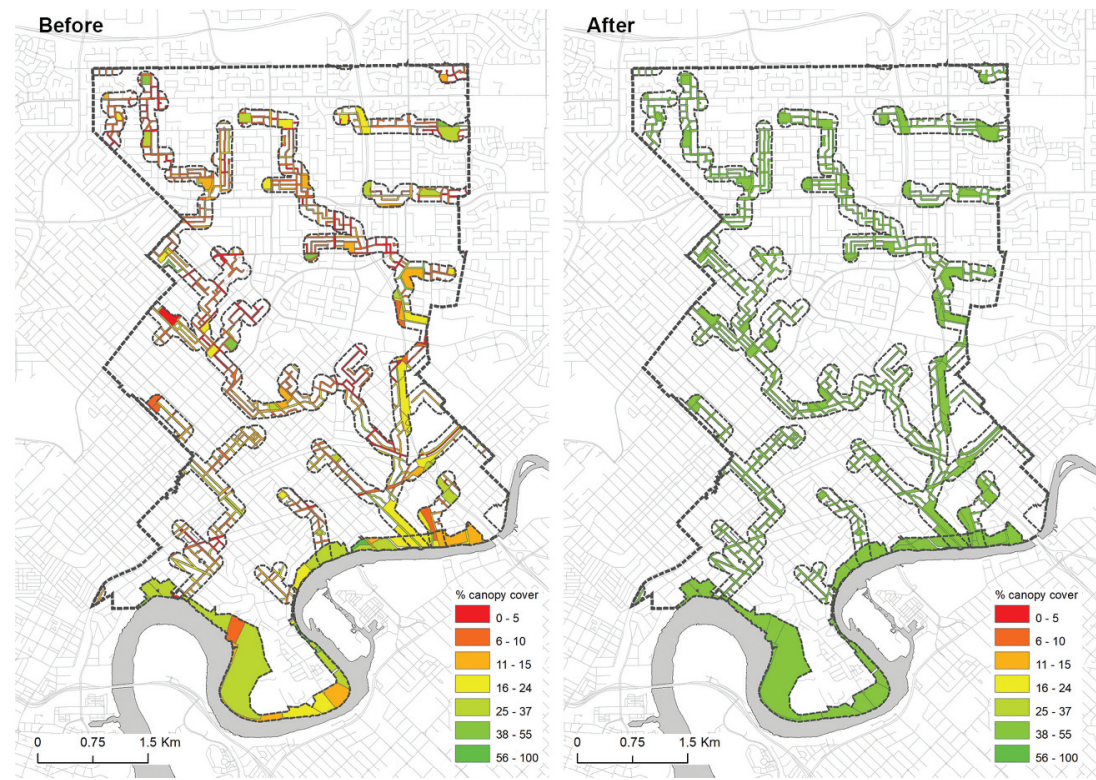

Figure 12. The Green Stream: To achieve the City of Bayswater's overall target of a 7\% increase in canopy cover requires drainage reserves, foreshore parks and select streets to increase from 12 to $52 \%$ canopy cover. 
Some respondents felt that this scenario provided positive 'outcomes such as connectivity for people and biodiversity' and a 'better spread of ecosystem services through the city's underutilized spaces' as well as 'improving water quality.' Nonetheless, most respondents felt that the scenario would cost 'a hell of a lot more' because it requires the 'reshaping of drains', and as such 'for the dollars you spend, and the trees you are getting, there is just no comparison.' Others noted that this scenario 'would require agreement with WaterCorp,' the government department responsible for the management of drains, who do not have a mandate for increasing tree canopy cover. Moreover, respondents felt there would be 'challenges planting in drainage channels behind private properties' that will 'also limit access to the drain for maintenance.' Other respondents felt that attitudes with the WaterCorp are slowly changing:

They are not as averse to things as they used to be. They used to be very against any sort of refraction in a drain, but they are open to all riffles and that sort of thing now. And you never know, they may start doing it them self-one day.

Nonetheless, respondents were generally pessimistic that Watercorp would lift restrictions in drainage corridors to sustain substantial tree planting.

\section{The Green Micro-Grid}

In this fifth ranking scenario, tree planting was focussed in major corridors connecting transit hubs, parks and schools with an overarching aim of increasing active transport to amenities but also existing and proposed train stations so to increase mass transit usage. To achieve the City's overall target of a seven per cent increase in canopy cover required these streets - and adjacent parks - to go from 12 to 43\% canopy cover (Figures 13 and 14).

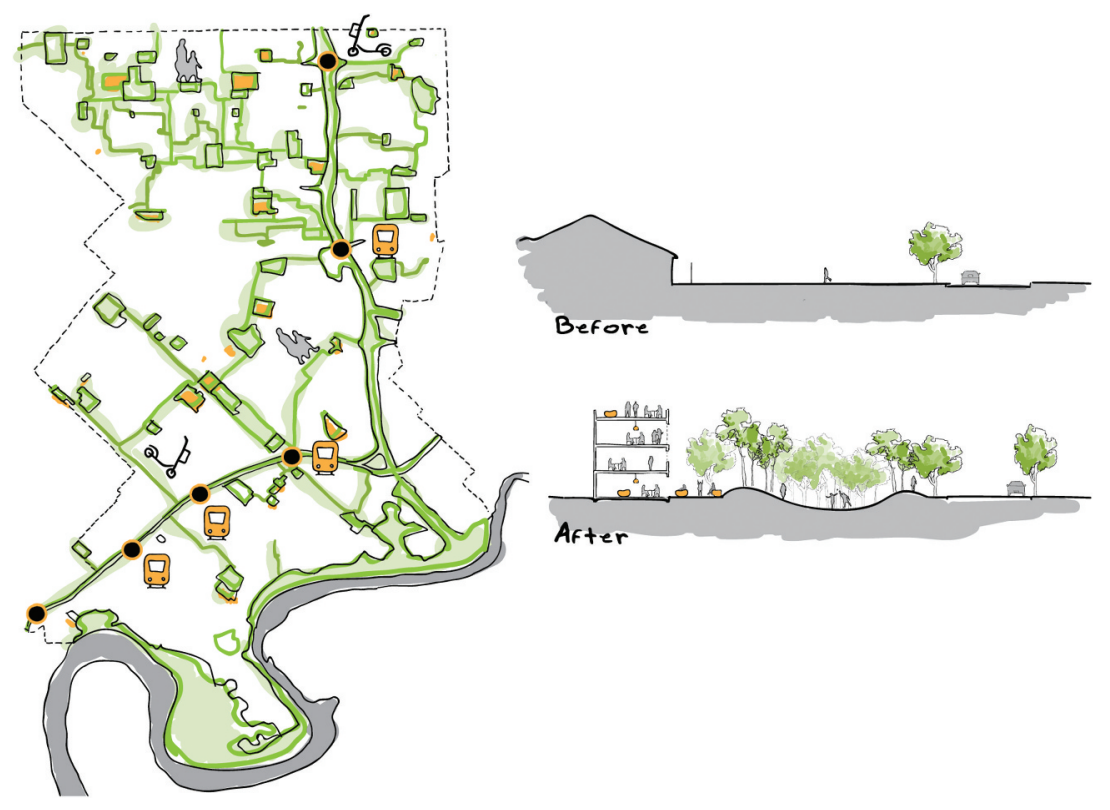

Figure 13. Green micro-grid: In this concept tree planting was focussed in major connecting transit hubs, parks and schools with an overarching aim of increasing active transport to amenities but also existing and proposed train stations so to increase mass transit usage. 

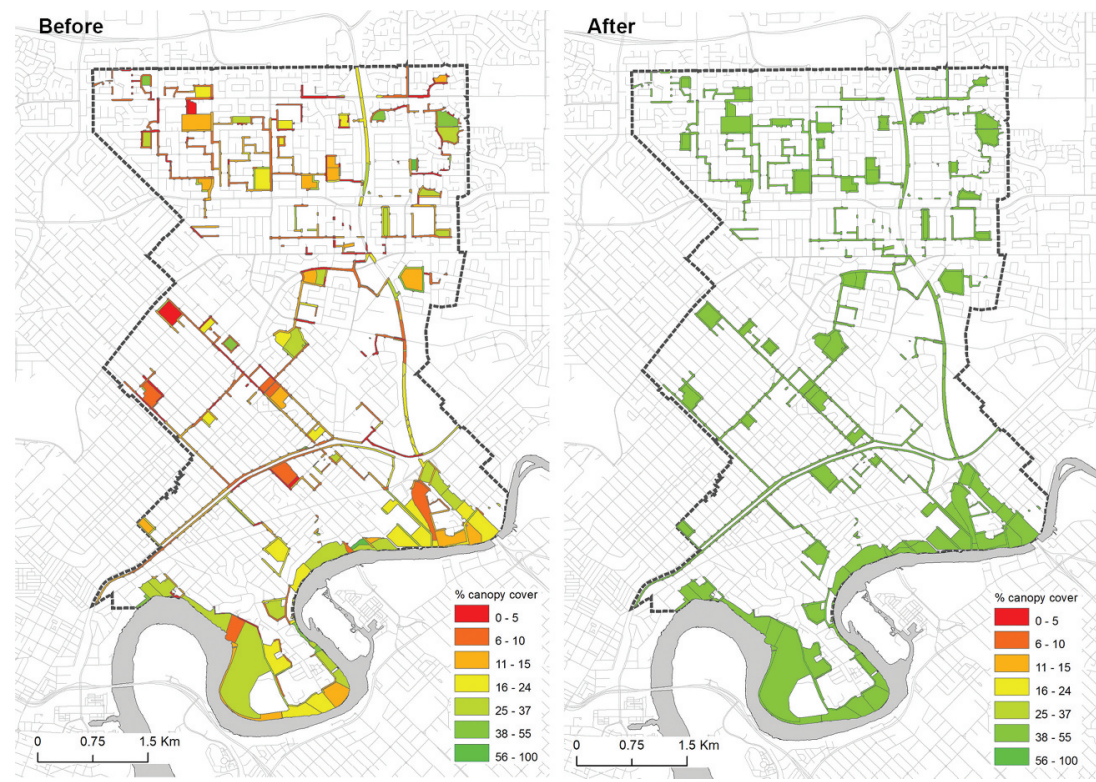

Figure 14. Green micro-grid: To achieve the City of Bayswater's overall target of a 7\% increase in canopy cover requires these streets - and adjacent parks - to go from 12 to $43 \%$ canopy cover.

Respondents raised concerns about this scheme, as tree planting on the verges of major roads is problematic because there is often competition for space, so civil works may also be required to accommodate tree planting which could push the cost up. Moreover, respondents felt the scenario was inequitable because 'local streets missed out.'

\section{The Green Funnel}

In this low ranking scenario, tree planting was focussed in streets, parks, and private land in areas the City of Bayswater has designated biodiversity corridors. This scenario aimed to create an urban forest to provide essential refugia for biodiversity and 'stepping stones' that facilitate species movement through the urban landscape (Threlfall et al. 2017). To achieve the City's overall target of a seven per cent increase in canopy cover requires these areas to increase from 12 to $20 \%$ canopy cover (Figures 15 and 16).

Some respondents noted that 'this biodiversity corridor stuff does resonate with a lot of people' and that the scenario would have 'good outcomes for biodiversity' however most comments were negative. In particular, respondents felt that the scenario would be difficult to implement because it requires the planting of trees on private land, ${ }^{1}$ a situation which would be even more challenging in 'areas zoned for high density' due to perceived 'root damage and the leaf litter.' Other respondents felt that the scheme would deliver benefits only 'to those living within the corridors or close to them.' 


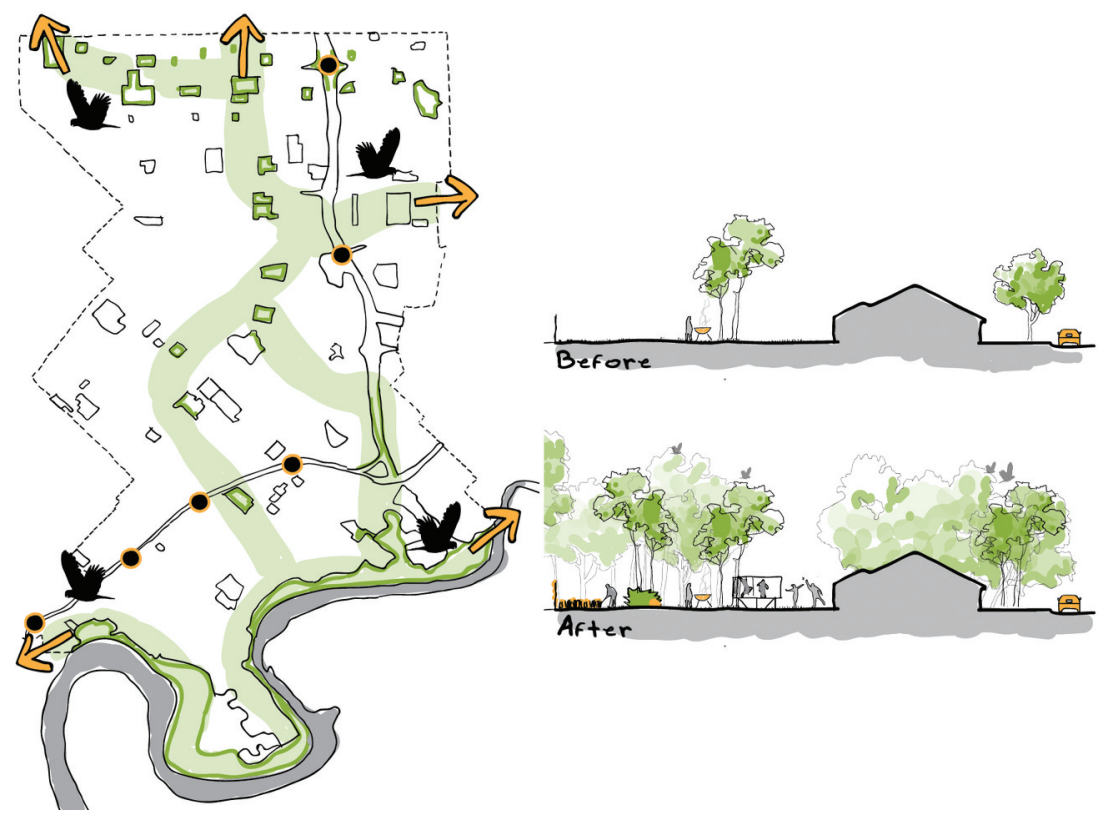

Figure 15. The green funnel: In this concept, tree planting was focussed in streets, parks, and private land along areas the City of Bayswater have designated biodiversity corridors.
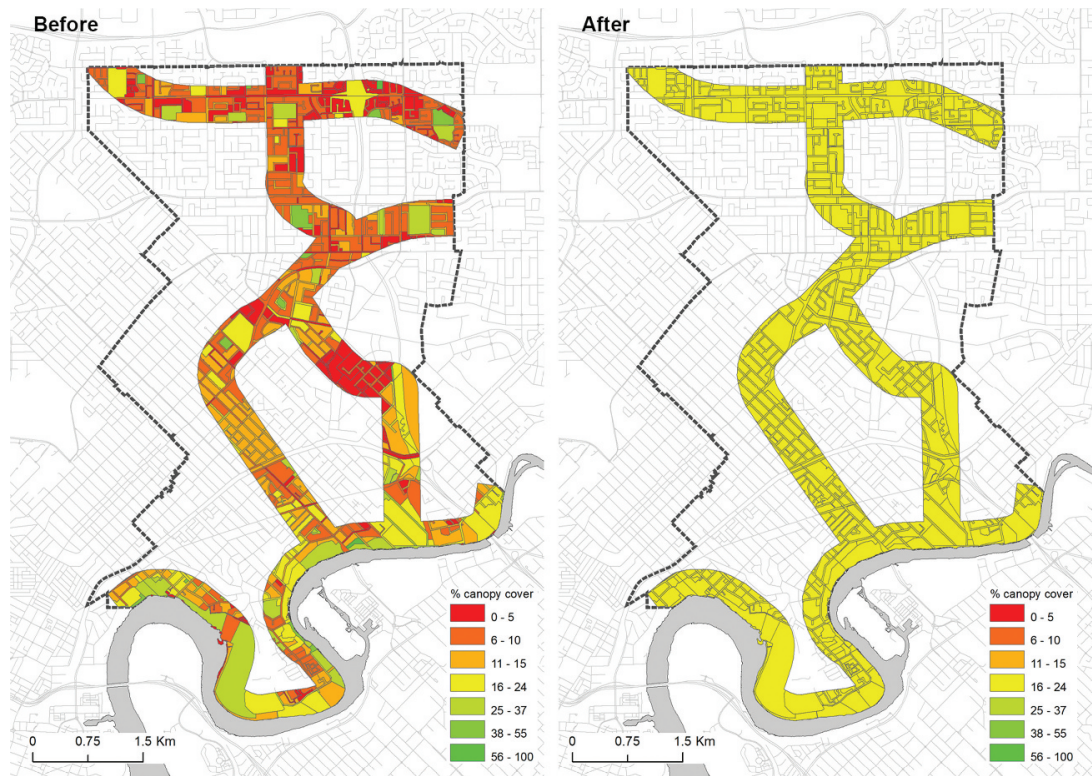

Figure 16. The green funnel: To achieve the City of Bayswater's overall target of a $7 \%$ increase in canopy cover requires these zones to go from 12 to $20 \%$ canopy cover. 


\section{The high-density forest}

In this lowest ranked scenario, tree planting was focussed in areas of the Local Government Area which the City of Bayswater has zoned for increased urban densities between R25 and above. To achieve the City's overall target of a seven per cent increase in canopy cover required these parks and streets to increase from 13 to 63\% canopy cover (Figures 17 and 18).

Respondents raised numerous concerns about this scenario. They felt that the scenario is inequitable and would deliver 'benefits for only some of the community, which is not fair' and would 'split the community.' Others raised issues with the theming of the scenario about urban density which they felt would elicit adverse community reactions, and that 'it is not as good a story as the schoolkids one' (e.g., 'The kid's forest'). Finally, respondents felt that the scenario would be difficult for the City of Bayswater to implement because of 'potential issues with servicing and space for trees in higher density areas.'

\section{Discussion}

In Perth and other densifying suburban cities, infill development is occurring at the expense of urban forests and the ecosystem services they provide. Because of this, policymakers and practitioners require urban forest scenarios that have been tested against expert opinion. This paper purposefully sets out seven urban forest scenarios to address this gap that could stimulate public interest and support. Finally, the paper tested these scenarios against expert opinion in a two-stage Delphi method to ensure their validity.

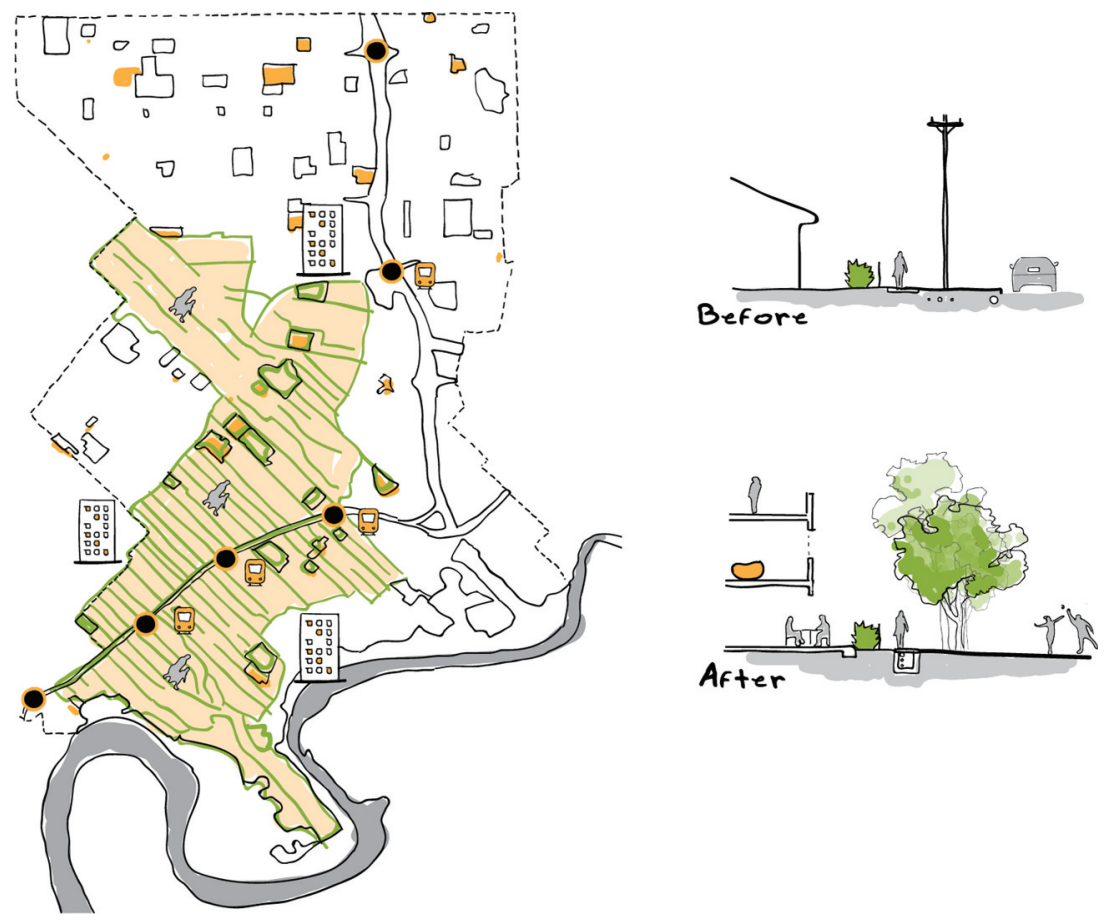

Figure 17. High-Density Forest: In this lowest ranked concept, tree planting was focussed in areas of the City of Bayswater which are zoned for urban densities between 25 to 40 dwellings per hectare but also areas with Activity Centre zonings. 

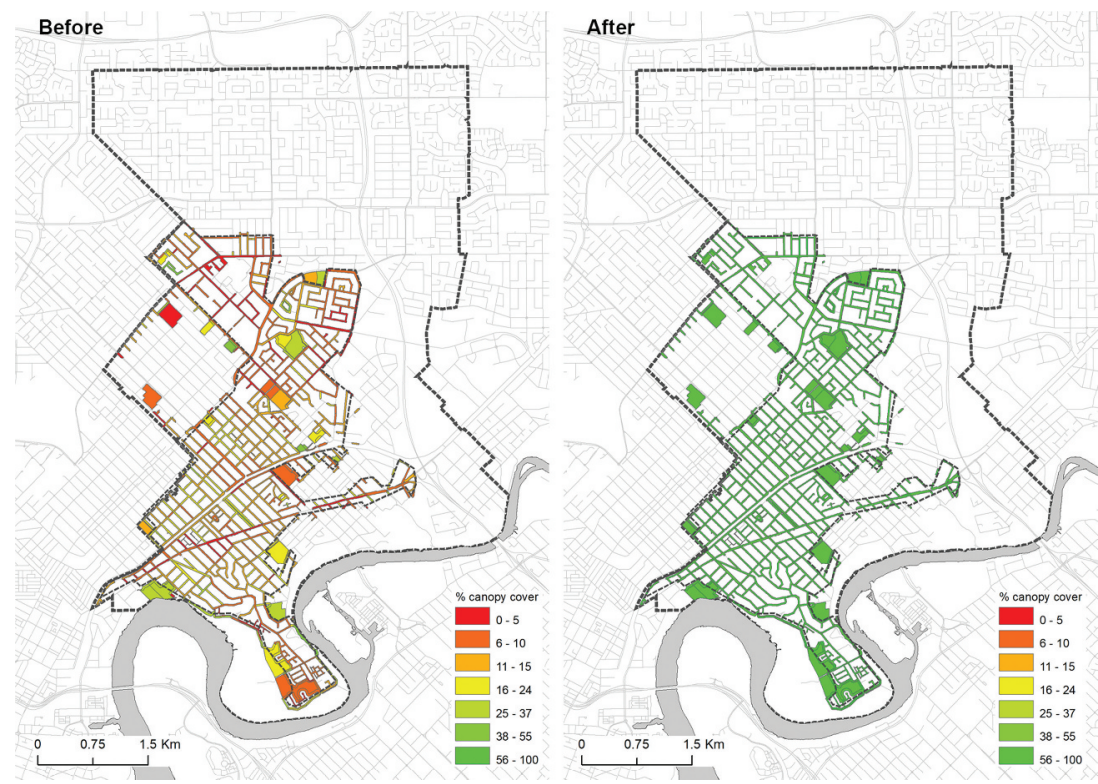

Figure 18. High- Density Forest: To achieve the City of Bayswater's overall target of a $7 \%$ increase in canopy cover requires these zones to go from 13 to 63\% canopy cover.

This review had some limitations. Due to project constraints, it was not possible to include non-expert stakeholders such as community members in the scenario evaluation process, something that is intended in a possible second phase of research for the City of Bayswater. Nonetheless, expert assessments of the urban forest scenarios in this paper were made concerning criteria that community members had developed in a comprehensive workshop process (City of Bayswater 2015, 15). The sample $(\mathrm{N}=11)$, was not large; however, this number is firmly within the established range of between 5 and 20 participants required for Delphi surveys (Hyndman and Athanasopoulos 2018). Nonetheless, increased numbers with different combinations of expertise could change the results.

The findings of our surveys indicate that rather than urban forest planning merely constituting a technical exercise to deliver a targeted increase in the canopy it should embody an overarching theme or narrative which defines a place identity and can both elicit community support and stewardship (Barron, Sheppard, and Condon 2016, 12). As Kim Dovey identifies 'one of the major blockages to transformational change has been a lack of design vision that can capture the public imagination for more sustainable urban futures' (Dovey and Woodcock 2014 , 1). Indeed, a participant in our study referred to a neighbouring Local Government Area, whose urban forest strategy had floundered because 'they have got no story to sell,' as opposed to the narrative dimension of scenarios such as the 'Kid's Forest.' As they noted:

I would like to get kids involved in planting immediately around the schools. Like on the actual school verges, and then educate the kids a little bit more about tree benefits. Because then they will take that message home to mom and dad. And that is always a little bit of a sneaky driver for us. A bit of a sneaky ploy on our part, to then get the message out further. And then the kids are saying, 'Oh, can we plant a tree on our verge mom and dad?' 
This finding suggests that placemaking and co-governance are important components of successful urban forestry strategies and initiatives. This resonates with the literature on placemaking. Placemaking is a process of enhancing local place identity through a combination of place-specific design and community involvement (Porter 2015, 17) which seeks to strengthen the connection between people and places (Project for Public Spaces 2018). This place-specific design typically brings 'a certain coherence to the multiform reality around us.' Landscapes, from urban gardens and development sites through to protected wilderness areas, are 'increasingly subject to a coherent system of identity construction' (Porter 2015, 84). However, this has rarely been applied to urban forests or their planning.

There remains a question as to the appropriate scale of such place-making and design-led urban forest planning. Indeed, within the Bayswater Local Government Area respondents noted that some suburbs were particularly resistant to increased canopy cover. In contrast, others were supportive, a divergent situation which reflects that our cities are becoming increasingly more socially and culturally diverse (Gulsrud, Hertzog, and Shears 2018, 164). As such, planners need to tailor urban forest planning to respond to community aspirations that vary between Local Government Areas, suburbs, neighbourhoods and even street blocks. Barron attests that the neighbourhood scale is an significant and oft-missed opportunity to connect dwellers with urban forestry planning. At this scale, 'design interventions and indicators connect with tangible and realisable outcomes that directly connect to people's lives' (Barron et al. 2019, 3).

Regardless of the scale, such place-making approaches to urban forest planning are not without risks. Socio-cultural examples of place-based meaning that divergent socio-cultural groups in an urban population ascribe to landscape vary drastically. One example is that neighbourhood parks can serve as social 'territories' of ethnic groups where some perceive a 'sense of belonging and others can feel excluded' (Gulsrud, Hertzog, and Shears 2018, 159). Concerning this study, it is yet to be tested whether residents without children would embrace a scenario such as The Kid's Forest, and certainly, this is worthy of further research. Moreover, by seeking to control the way the landscape identity is imagined, place branding can threaten landscape diversity (Porter 2017, 89). This constructed place identity can also conflict with intangible yet 'deeply-personal and subjective conceptions of place' (Gulsrud, Hertzog, and Shears 2018, 159).

Despite these issues without adequate long-term stewardship by communities, tree survival is likely to be negatively impacted (Carmichael and McDonough 2019,601). Stewardship is particularly important because many cities have reducing budgets for such projects because there has occurred a recent transferral of responsibilities for services from government to the private, community and voluntary sectors (Carmichael and McDonough 2019, 601). In this context, urban forest planning that fosters place identity that is collectively shared (Gulsrud, Hertzog, and Shears 2018, 159) will be of critical importance. This situation implies that urban forest planning should grow from being a technical exercise into one in which landscapes become a 'work of art' (Porter 2015, 15) embodying place-based narratives.

\section{Conclusion}

This paper has tabled seven scenarios for distributing a seven per cent increase in the City of Bayswater's urban canopy cover and orchestrated an expert evaluation of these scenarios via a detailed Delphi analysis. The results indicate that developing urban forest plans that have a narrative dimension and target the often-vulnerable demographics - 
such as children and the elderly - are likely to resonate with experts and communities as opposed to merely technical exercises in numerical canopy cover provision. Dr Robert McDonald, the Lead Scientist for the Global Cities programme at The Nature Conservancy, predicts that 'the most successful cities in the twenty-first century will do the best job of protecting the ecosystem services on which they depend' (McDonald 2015, 238). This modest urban forest plan and paper is directed towards this end.

\section{Note}

1. Community opinion is that the City should not regulate on private land. This is due to the perceived unfairness of allowing past developments to maximize their profits whilst potentially limiting the profits made on future developments (City of Bayswater 2015, 18).

\section{Acknowledgments}

The authors would like to thank Jeremy Maher, who supported this research in his role as Manager of Sustainability and Environment at the City of Bayswater.

\section{Disclosure statement}

No potential conflict of interest was reported by the authors.

\section{Funding}

This work was supported by the City of Bayswater.

\section{ORCID}

Julian Bolleter (iD http://orcid.org/0000-0002-1514-2007

\section{References}

Astell-Burt, T., R. Mitchell, and T. Hartig. 2014. "The Association between Green Space and Mental Health Varies across the Lifecourse. A Longitudinal Study." Journal of Epidemiology and Community Health 68 (6): 578-583. doi:10.1136/jech-2013-203767.

Astell-Burt, T., and X. Feng. 2019. "Association of Urban Green Space with Mental Health and General Health among Adults in Australia." JAMA Network Open 2 (7): e198209-e198209. doi:10.1001/ jamanetworkopen.2019.8209.

Australian Bureau of Statistics. 2013. "Population Projections, Australia, 2012 to 2101." Australian Bureau of Statistics. Accessed January 3. http://www.abs.gov.au/ausstats/abs@.nsf/Lookup/3222. Omain+features $52012 \% 20$ (base)\%20to\%202101

Barron, S., S. Nitoslawski, K. L. Wolf, A. Woo, E. Desautels, and S. R. J. Sheppard. 2019. "Greening Blocks: A Conceptual Typology of Practical Design Interventions to Integrate Health and Climate Resilience Co-benefits." International Journal of Environmental Research and Public Health 16 (21): 4241. doi:10.3390/ijerph16214241.

Barron, S., S. R. J. Sheppard, and P. M. Condon. 2016. “Urban Forest Indicators for Planning and Designing Future Forests." Forests 7 (9): 208. doi:10.3390/f7090208. 
Bell, J. F., J. S. Wilson, and G. C. Liu. 2008. "Neighborhood Greenness and 2-year Changes in Body Mass Index of Children and Youth." American Journal of Preventive Medicine 35 (6): 547-553. doi:10.1016/j.amepre.2008.07.006.

Ben-Joseph, E. 2007. "Changing the Residential Street Scene: Adapting the Shared Street (Woonerf) Concept to the Suburban Environment." Journal of the American Planning Association 61 (4): 504-515. doi:10.1080/01944369508975661.

Bolleter, J. 2015. Scavenging the Suburbs: Auditing Perth for 1 Million Infill Dwellings. Perth: University of Western Australia Publishing.

Bolleter, J. 2016. "Background Noise: A Review of the Effects of Background Infill on Urban Liveability in Perth." Australian Planner 10: 1-14.

Bolleter, J. 2017. "Fringe Benefits? A Review of Outer Suburban Development on Perth's Fringes in Relation to State Government Goals Concerning the Natural Environment and Efficient Transport Connectivity." Australian Planner 54 (2): 93-114. doi:10.1080/07293682.2017.1319395.

Bolleter, J., and C. Ramalho. 2014. "The Potential of Ecologically Enhanced Urban Parks to Encourage and Catalyze Densification in Greyfield Suburbs." Journal of Landscape Architecture 9 (3): 54-65. doi:10.1080/18626033.2015.968418.

Bolleter, J., and C. Ramalho. 2019. Greenspace-Oriented Development: Reconciling Urban Density and Nature in Suburban Cities. London: Springer.

Bolund, P., and S. Hunhammar. 1999. "Ecosystem Services in Urban Areas." Ecological Economics 29 (2): 293-301. doi:10.1016/S0921-8009(99)00013-0.

Brunner, J., and P. Cozens. 2013. "'Where Have All the Trees Gone?' Urban Consolidation and the Demise of Urban Vegetation: A Case Study from Western Australia." Planning Practice \& Research 28 (2): 231-255. doi:10.1080/02697459.2012.733525.

Byrne, J., N. Sipe, and G. Searle. 2010. "Green around the Gills? The Challenge of Density for Urban Greenspace Planning in SEQ." Australian Planner 47 (3): 162-177. doi:10.1080/07293682.2010.508204.

Calthorpe, P., and W. Fulton. 2015. "Designing the Region and Designing the Region Is Designing the Neighbourhood." In The City Reader, edited by R. T. LeGates and F. Stout, 331-336. London: Routledge.

Campbell, L. K., E. S. Svendsen, and L. A. Roman. 2016. "Knowledge Co-production at the Researchpractice Interface: Embedded Case Studies from Urban Forestry." Environmental Management 57 (6): 1262-1280. doi:10.1007/s00267-016-0680-8.

Carmichael, C. E., and M. H. McDonough. 2019. "Community Stories: Explaining Resistance to Street Tree-planting Programs in Detroit, Michigan, USA." Society \& Natural Resources 32 (5): 588-605. doi:10.1080/08941920.2018.1550229.

City of Bayswater. 2015. Greening Our Garden City. Perth: City of Bayswater.

City of Bayswater. 2018. Trees on Private Land and Street Verges. Perth: City of Bayswater.

City of Melbourne. 2012. Urban Forest Strategy: Making a Great City Greener. Melbourne: City of Melbourne.

City of Vancouver. 2018. Urban Forest Strategy. Vancouver: City of Vancouver.

Coutts, A. M., E. C. White, N. J. Tapper, J. Beringer, and S. J. Livesley. 2016. "Temperature and Human Thermal Comfort Effects of Street Trees across Three Contrasting Street Canyon Environments." Theoretical and Applied Climatology 124 (1-2): 55-68. doi:10.1007/s00704-015-1409-y.

Cox, D. T. C., J. Bennie, S. Casalegno, H. L. Hudson, K. Anderson, and K. J. Gaston. 2019. "Skewed Contributions of Individual Trees to Indirect Nature Experiences." Landscape and Urban Planning 185: 28-34. doi:10.1016/j.landurbplan.2019.01.008.

Department of Planning. "Urban Forests of Perth and Peel." Government of Western Australia. Accessed September 21. http://www.planning.wa.gov.au/publications/7216.asp

Department of Planning Lands and Heritage. 2018. Better Urban Forest Planning. Perth: Department of Planning Lands and Heritage.

Department of Planning Lands and Heritage. 2016. Urban Forest Mesh Blocks. Edited By. Perth: Department of Planning Lands and Heritage.

Department of Planning, and Western Australian Planning Commission. 2014. Urban Growth Monitor: Perth Metropolitan, Peel and Greater Bunbury Regions. Perth: Western Australian Planning Commission. 
Dodson, J., and N. Sipe. 2008. Unsettling Suburbia: The New Landscape of Oil and Mortgage Vulnerability in Australian Cities. Brisbane: Griffith University.

Dovey, K., and I. Woodcock. 2014. Intensifying Melbourne: Transit-orientated Urban Design for Resilient Urban Futures. Melbourne: Melbourne School of Design, The University of Melbourne.

Duncan, J. M. A., B. Boruff, A. Saunders, Q. Sun, J. Hurley, and M. Amati. 2019. "Turning down the Heat: An Enhanced Understanding of the Relationship between Urban Vegetation and Surface Temperature at the City Scale." Science of the Total Environment 656: 118-128. doi:10.1016/j. scitotenv.2018.11.223.

Dunn, R. R., M. C. Gavin, M. C. Sanchez, and J. N. Solomon. 2006. "The Pigeon Paradox: Dependence of Global Conservation on Urban Nature." Conservation Biology 20 (6): 1814-1816. doi:10.1111/ j.1523-1739.2006.00533.x.

Gulsrud, N. M., K. Hertzog, and I. Shears. 2018. "Innovative Urban Forestry Governance in Melbourne?: Investigating "Green Placemaking" as a Nature-based Solution." Environmental Research 161: 158-167. doi:10.1016/j.envres.2017.11.005.

Haaland, C., and C. K. van den Bosch. 2015. "Challenges and Strategies for Urban Green-space Planning in Cities Undergoing Densification: A Review." Urban Forestry \& Urban Greening 14 (4): 760-771. doi:10.1016/j.ufug.2015.07.009.

Hagan, S. 2017. "Metabolic Suburbs or the Virtue of Low Densities." In Infinite Suburbia, edited by A. Berger, J. Kotkin, and C. Guzman, 468-477. Boston: MIT.

Hartig, T., R. Mitchell, S. De Vries, and H. Frumkin. 2014. "Nature and Health." Annual Review of Public Health 35: 207-228.

Hooper, P., M. Knuiman, S. Foster, and B. Giles-Corti. 2015. "The Building Blocks of a 'Liveable Neighbourhood': Identifying the Key Performance Indicators for Walking of an Operational Planning Policy in Perth, Western Australia." Health \& Place 36: 173-183. doi:10.1016/j. healthplace.2015.10.005.

Hurley, J., E. Taylor, and J. Dodson. 2017. "Why Has Urban Consolidation Been so Difficult?" In The Routledge Handbook of Australian Urban and Regional Planning, edited by N. Sipe and K. Vella, 123-135. New York: Routledge.

Hyndman, R. J., and G. Athanasopoulos. 2018. Forecasting: Principles and Practice. Melbourne: OTexts.

Ikin, K., E. Knight, D. B. Lindenmayer, J. Fischer, and A. D. Manning. 2013. "The Influence of Native versus Exotic Streetscape Vegetation on the Spatial Distribution of Birds in Suburbs and Reserves." Diversity and Distributions 19 (3): 294-306. doi:10.1111/j.1472-4642.2012.00937.x.

Ives, C. D., P. E. Lentini, C. G. Threlfall, K. Ikin, D. F. Shanahan, G. E. Garrard, S. A. Bekessy, R. A. Fuller, L. Mumaw, and L. Rayner. 2016. "Cities are Hotspots for Threatened Species." Global Ecology and Biogeography 25 (1): 117-126. doi:10.1111/geb.12404.

Kaźmierczak, A. 2013. "The Contribution of Local Parks to Neighbourhood Social Ties." Landscape and Urban Planning 109 (1): 31-44. doi:10.1016/j.landurbplan.2012.05.007.

Kelley, K., B. Clark, V. Brown, and J. Sitzia. 2003. "Good Practice in the Conduct and Reporting of Survey Research." International Journal for Quality in Health Care 15 (3): 261-266. doi:10.1093/intqhc/mzg031.

Kelly, J.-F., P. Breadon, and J. Reichl. 2011. Getting the Housing We Want. Melbourne: Grattan Institute.

Kovats, R. S., and S. Hajat. 2008. "Heat Stress and Public Health: A Critical Review." Annual Review of Public Health 29 (1): 41-55. doi:10.1146/annurev.publhealth.29.020907.090843.

Lenzholzer, S. 2015. Weather in the City: How Design Shapes the Urban Climate. Rotterdam: nai010.

Maas, J., S. M. E. van Dillen, R. A. Verheij, and P. P. Groenewegen. 2009. "Social Contacts as a Possible Mechanism behind the Relation between Green Space and Health." Health \& Place 15 (2): 586-595. doi:10.1016/j.healthplace.2008.09.006.

McDonald, R. 2015. Conservation for Cities: How to Plan and Build Natural Infrastructure. Washington: Island Press.

McManus, P. 2010. "Planning with and for Trees in Perth: Yesterday, Today and Tomorrow." In Planning Perspectives from Western Australia: A Reader in Theory and Practice, edited by I. Alexander, S. Greive, and D. Hedgcock, 340-353. Perth: Fremantle Press.

Miller, J. R. 2005. "Biodiversity Conservation and the Extinction of Experience." Trends in Ecology and Evolution 20 (8): 430-434. doi:10.1016/j.tree.2005.05.013. 
Miller, J. R., and R. J. Hobbs. 2002. "Conservation Where People Live and Work." Conservation Biology 16 (2): 330-337.

Mullaney, J., T. Lucke, and S. J. Trueman. 2015. "A Review of Benefits and Challenges in Growing Street Trees in Paved Urban Environments." Landscape and Urban Planning 134: 157-166. doi:10.1016/j.landurbplan.2014.10.013.

Newman, P., T. Beatley, and H. Boyer. 2009. Resilient Cities. Washington, DC: Island Press.

Nitoslawski, S. A., P. N. Duinker, and P. G. Bush. 2016. "A Review of Drivers of Tree Diversity in Suburban Areas: Research Needs for North American Cities." Environmental Reviews 24 (4): 471-483. doi:10.1139/er-2016-0027.

Nouri, H., S. Beecham, F. Kazemi, and A. M. Hassanli. 2013. "A Review of ET Measurement Techniques for Estimating the Water Requirements of Urban Landscape Vegetation." Urban Water Journal 10 (4): 247-259. doi:10.1080/1573062X.2012.726360.

Ossola, A., A. K. Hahs, and S. J. Livesley. 2015. "Habitat Complexity Influences Fine Scale Hydrological Processes and the Incidence of Stormwater Runoff in Managed Urban Ecosystems." Journal of Environmental Management 159: 1-10. doi:10.1016/j.jenvman.2015.05.002.

Pandit, R., M. Polyakov, and R. Sadler. 2014. "Valuing Public and Private Urban Tree Canopy Cover." Australian Journal of Agricultural and Resource Economics 58 (3): 453-470. doi:10.1111/14678489.12037.

Pandit, R., M. Polyakov, S. Tapsuwam, and T. Moran. 2013. "The Effect of Street Trees on Property Value in Perth, Western Australia." Landscape and Urban Planning 110: 134-142. doi:10.1016/j. landurbplan.2012.11.001.

Panduro, T. E., and K. L. Veie. 2013. "Classification and Valuation of Urban Green Spaces - A Hedonic House Price Valuation." Landscape and Urban Planning 120: 119-128. doi:10.1016/j. landurbplan.2013.08.009.

Pereira, G., H. Christian, S. Foster, B. J. Boruff, F. Bull, M. Knuiman, and B. Giles-Corti. 2013. "The Association between Neighborhood Greenness and Weight Status: An Observational Study in Perth, Western Australia." Environmental Health 12 (1): 49. doi:10.1186/1476-069X-12-49.

Perveen, S., M. Kamruzzaman, and T. Yigitcanlar. 2017. "Developing Policy Scenarios for Sustainable Urban Growth Management: A Delphi Approach." Sustainability 9 (10): 1787. doi:10.3390/su9101787.

Porter, N. 2015. Landscape and Branding: The Promotion and Production of Place. Abingdon, UK: Routledge.

Porter, N. 2017. "Branding Landscape." LA+ 5: 84-89.

Project for Public Spaces. 2018. "What Is Placemaking?" Project for Public Spaces. Accessed May 9. https://www.pps.org/article/what-is-placemaking

Schwartz, M. W., N. L. Jurjavcic, and J. M. O'brien. 2002. "Conservation's Disenfranchised Urban Poor." BioScience 52 (7): 601-606. doi:10.1641/0006-3568(2002)052.

Swaffield, S., and E. Deming. 2010. Landscape Architecture Research. New Jersey: Wiley.

Threlfall, C. G., K. Walker, N. S. G. Williams, A. K. Hahs, L. Mata, N. Stork, and S. J. Livesley. 2015. "The Conservation Value of Urban Green Space Habitats for Australian Native Bee Communities." Biological Conservation 187: 240-248. doi:10.1016/j.biocon.2015.05.003.

Threlfall, C. G., L. Mata, J. A. Mackie, A. K. Hahs, N. E. Stork, N. S. G. Williams, and S. J. Livesley. 2017. "Increasing Biodiversity in Urban Green Spaces through Simple Vegetation Interventions." Journal of Applied Ecology 54 (6): 1874-1883. doi:10.1111/1365-2664.12876.

Timperio, A., B. Giles-Corti, D. Crawford, N. Andrianopoulos, K. Ball, J. Salmon, and C. Hume. 2008. "Features of Public Open Spaces and Physical Activity among Children: Findings from the CLAN Study." Preventive Medicine 47 (5): 514-518. doi:10.1016/j.ypmed.2008.07.015.

Tzoulas, K., K. Korpela, S. Venn, V. Yli-Pelkonen, A. Kazmierczak, J. Niemela, and P. James. 2007. "Promoting Ecosystem and Human Health in Urban Areas Using Green Infrastructure: A Literature Review." Landscape and Urban Planning 81 (3): 167-178. doi:10.1016/j.landurbplan.2007.02.001.

Ulrich, R. S. 1984. "View through a Window May Influence Recovery from Surgery." Science 224 (4647): 420-421. doi:10.1126/science.6143402.

van den Born, R. J. G., B. Arts, J. Admiraal, A. Beringer, P. Knights, E. Molinario, K. Polajnar Horvat, C. Porras-Gomez, A. Smrekar, and N. Soethe. 2018. "The Missing Pillar: Eudemonic Values in the 
Justification of Nature Conservation." Journal of Environmental Planning and Management 61 (5-6): 841-856. doi:10.1080/09640568.2017.1342612.

West Australian Planning Commission, and Department of Planning. 2015. R-Codes Amendments 2015. Perth: Department of Planning.

Western Australian Department of Planning. 2010. Directions 2031 and Beyond: Metropolitan Planning beyond the Horizon. Perth: Department of Planning.

Wong, T. 2006. "Water Sensitive Urban Design- the Journey Thus Far." Australian Journal of Water Resources 10 (3): 213-220. doi:10.1080/13241583.2006.11465296.

Yelenik, S. G., and J. M. Levine. 2011. "The Role of Plant-soil Feedbacks in Driving Native-species Recovery." Ecology 92 (1): 66-74. doi:10.1890/10-0465.1. 